\title{
Testing for persistence in mutual fund performance and the ex post verification problem: Evidence from the Greek market
}

\author{
Vassilios Babalos, Guglielmo Maria Caporale ${ }^{\dagger}$, Alexandros Kostakis ${ }^{\ddagger}$ and Nikolaos Philippas ${ }^{\S}$
}

\begin{abstract}
The present study examines a series of performance measures as an attempt to resolve the ex post verification problem. These measures are employed to test the performance persistence hypothesis of domestic equity funds in Greece, during the period 1998-2004. Correctly adjusting for risk factors and documented portfolio strategies explains a significant part of the reported persistence. The intercept of the augmented Carhart regression is proposed as the most appropriate performance measure. Using this measure, weak evidence for persistence, only before 2001, is documented. The growth of the fund industry, the direction of flows to past winners and the integration in

*Department of Banking and Financial Management, University of Piraeus, Greece

$\dagger$ Department of Economics and Finance, Brunel University, London. Corresponding author. Postal address: Brunel University, Uxbridge, Middlesex UB8 3PH, UK. Tel.: +44 (0)1895 266713. Fax: +44 (0)1895 269770. E-mail: GuglielmoMaria.Caporale@brunel.ac.uk

${ }^{\ddagger}$ Department of Economics and Related Studies, University of York, YO10 5DD, York, UK. E-mail: ak196@york.ac.uk

$\S$ Department of Business Administration, University of Piraeus, Greece. E-mail: phili-
\end{abstract} pas@unipi.gr 
the international financial system are suggested to be the reasons for the absence of performance persistence.

JEL Classification: G14, G15, G21, G23

Keywords: Mutual funds, Performance persistence, Market efficiency, Emerging markets. 


\section{Introduction}

The mutual fund industry has experienced a dramatic growth on a global basis during the last two decades. Mutual funds are now the preferred investment vehicle for individuals. Their outstanding success is due to the fact that they provide access to professional management and a highly diversified portfolio even for investors with low initial capital. In a world of perfect competition and symmetric information, investing in actively managed mutual funds is Pareto efficient from a welfare point of view.

However, given the delegated nature of active fund management, a series of problems related to asymmetric information may occur. Asymmetric information between the mutual fund shareholder and the manager can arise in three stages (see Spencer, 2000, for an analytical discussion of asymmetric information issues in financial markets). Firstly, there is the possibility of adverse selection. The most capable managers are more likely to get employed in different types of investment vehicles, where the compensation structure is more directly linked to their performance. Closed-end funds, hedge funds and private banking services could attract the best managers. Secondly, there is a moral hazard problem. Once investment has taken place, the manager could attempt to expropriate wealth from the investors, most commonly by charging a high expense ratio. Thirdly, there is the issue of ex post verification, i.e. of fairly evaluating the investment outcome. For this purpose, researchers have suggested various performance measures, according to which managers should be classified and rewarded.

The problems arising from asymmetric information are even more severe in small and emerging markets with oligopolistic fund industries and vertically integrated financial systems. In such markets, managers are more likely to obtain insider information which they can exploit in their own interest. Furthermore, high expense ratios are often observed, given the lack of transparency and competition between fund companies. The insufficient regulatory framework and financial knowledge of investors, common features 
of emerging markets, make fund management screening and evaluation an even more difficult task in this case.

Various performance measures have been suggested in the literature. In order to take into account underlying risk factors, mutual funds are classified as Winners (W) or Losers (L) using one of the following criteria: raw returns, the Sharpe (1966) ratio, Jensen (1968)'s alpha, its augmented version suggested by Elton et al. (1996) and Gruber (1996), Carhart (1997)'s alpha, and its augmented version to take into account bond returns.

The most common measures are the Sharpe ratio and Jensen's alpha. The former adjusts returns using their variance, as in the mean-variance world of Markowitz (1952). Such a measure, however, creates an obvious incentive to undertake higher moments risks. This is common practice among hedge fund and bond fund managers in emerging markets. Since these risks are priced in financial markets (see Harvey and Siddique, 2000), they should be taken into account when evaluating managers. As for Jensen's alpha, this is rooted in the CAPM tradition. The CAPM is, in principle, a static representation of capital markets, which ignores their dynamic component. Therefore, it is an incomplete framework in the presence of stochastically evolving risk factors (see Merton, 1973). In fact, Size and Value strategies could yield positive returns without any CAPM beta exposure (see Fama and French, 1993, 1996), and the same applies to momentum strategies (see Jegadeesh and Titman, 1993).

The empirical evidence showing that these strategies systematically outperform alternative ones is puzzling ${ }^{1}$. Concluding that there is no risk factor underlying these strategies is equivalent to admitting "free lunches", in the spirit of Harrison and Kreps (1979). However, it has been suggested by Carhart (1997) that the Fama-French and momentum portfolios reflect specific

\footnotetext{
${ }^{1}$ See Barry et al. (2002) for the apparent success of size and value strategies in the case of emerging markets, and Rouwenhorst (1998) for that of momentum strategies in a series of international markets.
} 
risk factors and should be taken into account. In fact, Campbell and Vuolteenaho (2004) show that the Fama-French anomalies can be resolved in an intertemporal setting, while Petkova (2006) argues that these portfolios are correlated with shocks to a series of financial variables.

Employing multi-factor rather than single-factor measures might be a way to shed more light on this issue. However, whilst most recent studies testing for performance persistence in the US fund industry use multi-factor measures à la Carhart $^{2}$, few studies employ such measures in an international setting $^{3}$ and in the case of emerging markets. The present study contributes to this area of the literature by focusing on Greek domestic equity mutual funds during the period 1998-2004 and using such an approach, which adjusts for risk factors, thereby providing some new unbiased evidence for an additional market ${ }^{4}$. The case of Greece is particularly interesting to examine because the mutual fund industry is oligopolistic, and the Athens Stock Exchange (ASE) is relatively small in total capitalization and characterized by illiquidity. Moreover, the market is dominated by a few large size companies and some key market players. However, Greece is an emerging market quickly turning into a developed one, as a result of EMU membership and full integration in the international financial system. This is evident from the significant increase in the participation of foreign investors over the period analysed here (see Figure 2). Such institutional characteristics and the participation of foreign investors in the financial system might be important factors for fund performance and market efficiency also in other small or emerging markets. Our dataset being sufficiently long and comprehensive, it can capture the dynamic evolution of the industry, enabling us to evalu-

\footnotetext{
${ }^{2}$ The study of Bollen and Busse (2005) is a recent example.

${ }^{3}$ The studies of Fletcher and Forbes (2002), Tonks (2005) and Cuthbertson et al. (2006) for UK, Bilson et al. (2005) for Australia and Otten and Bams (2002) for European funds are among those which use multi-factor models.

${ }^{4}$ Khorana et al., (2005) stress the importance of wider and more reliable international evidence.
} 
ate mutual funds under different market conditions without the problem of survivorship bias.

Previewing our results, we find evidence for persistence over one-year horizons during the period 1998-2001. After 2001, persistence becomes very weak or disappears, depending on the employed performance measure. As we adjust for risk factors using more sophisticated measures and reducing the bias, the evidence for persistence becomes weaker. The most appropriate measure appears to be the augmented version of the Carhart one, which includes a bond index (often neglected, but extremely important, since equity funds use bonds to reduce their market risk exposure in periods of negative market returns - see Figure 3). The integration of the Greek market in the international financial system and the direction of flows to past winners are the two factors most likely to account for the lack of persistence after 2001. The increasing participation of foreign investors increases market efficiency, reducing the informational advantages of domestic fund managers. Furthermore, relatively high flows to past winners possibly generate a "dilution" effect, making it impossible for managers persistently to outperform others. As for the ex post verification problem, our findings imply that once excess returns are correctly decomposed and risk factors are taken into account, fund managers do not persistently add any extra value to their portfolios after 2001.

The layout of the paper is the following. Section 2 reviews the existing literature for the US and international markets. The main features of the Greek financial system and fund industry are briefly discussed in Section 3. Section 4 provides data sources and definitions and reviews various performance measures to test the persistence hypothesis. Section 5 presents the empirical evidence, whilst Section 6 contains concluding remarks and suggestions for future research. 


\section{Literature Review}

The literature on performance persistence is vast. Most studies have focused on the US market, but more recently there has been a growing interest in international markets. Sharpe (1966) and Jensen (1968) in their seminal papers introduced early measures of persistence. While Sharpe (1966) reported a significant relationship between the present and the past performance of mutual funds over 10-year horizons, Jensen (1968) concluded that future performance is not predictable. Carlson (1970), using risk-adjusted returns, found no evidence of persistence over 10-year horizons, and weak evidence for 5-year horizons.

Subsequently, Lehmann and Modest (1987) also reported evidence of persistence for US equity funds. Grinblatt and Titman (1989) argued that abnormal returns are not significant once transaction costs and management fees are calculated. However, Brown et al. (1992) suggested that the results of previous studies may have been spurious because of survivorship bias, and that therefore the reported persistence could be explained by the fact that only successful funds survive through time. Hendricks et al. (1993) and Goetzmann and Ibbotson (1994) argued that persistence is a short-lived phenomenon, while negative persistence was found even over longer horizons. Kahn and Rudd (1995) extended these results to bond funds. Malkiel (1995) provided evidence of lack of persistence in the 1980s, while Brown and Goetzmann (1995) reported persistence for short horizons taking into account the survivorship bias effect. Gruber (1996) examined whether raw and risk-adjusted returns can be predicted using performance measures, and showed that Jensen's alpha works better for the former.

Phelps and Detzel (1997) drew the distinction between macropersistence and micropersistence, the former being due to the persistence of a broad equity class, the latter to persistence in managerial ability. The study of Carhart (1997) had a significant impact on the literature, introducing a new measure of performance which adjusts for risk factors. Using this new meas- 
ure, he reported no overall persistence, only underperforming funds exhibiting some degree of persistence. Droms and Walker (2001) found no evidence of persistence over long-horizons, while Bollen and Busse (2005) suggested that persistence is by its nature a short-term phenomenon, to be found over short-term horizons such as quarterly periods.

Studies on markets other than the US one include some on the UK mutual fund industry. Examples are those of Blake and Timmermann (1998), who provided evidence of persistence over short horizons; Fletcher and Forbes (2002), who instead found no persistence using the Carhart measure; and Cuthbertson et al. (2005), who argued that few managers genuinely outperform, while most underperformers exhibit poor skill, not bad luck. As for other countries, Vos et al. (1995) found that future performance of Australian and New Zealand funds is not predictable using current performance measures. Cortez et al. (1999) examined persistence in Portuguese equity funds and reported that, if risk-adjusted returns are used, persistence disappears. Dahlquist et al. (2000) provided evidence of no persistence in their study of Swedish equity funds, while in Casarin et al. (2002) persistence was reported in the risk-adjusted returns of Italian equity funds, but only on a short-term basis. Deaves (2004) found persistence only over short horizons in Canada, whilst Agudo and Magallon (2005) provided mixed evidence for Spain. Christensen (2005) found no predictive ability of past performance measures in the case of Denmark. Finally, Otten and Bams (2002) found no persistence in equity funds from the largest European markets, apart from the case of the UK.

Table 1 summarises the findings from the aforementioned studies.

$$
\text { -Table } \quad 1-
$$




\section{The case of Greece}

The Athens Stock Exchange (ASE) was founded in 1876. Since 1991 the Capital Markets Commission has been the superintendent authority for all capital markets. The mutual fund industry was established in 1972 with the introduction of one equity and one hybrid fund. Since 1989, following institutional changes to the Greek capital market, the fund industry experienced rapid growth. While in 1985 there were only two state-controlled funds managing 4 billion drachmas, by December 2004 there existed 28 fund companies offering 262 funds of all types, 68 of which were domestic equity funds, and managing more than 31.65 billion Euros (an equivalent of 10.7 trillion drachmas). Figure 1 shows the number of domestic equity funds as well as the ASE General Index. Table 2 presents statistics on the equity fund industry and average returns of the funds compared with the returns on the ASE General Index. The extraordinary demand for equity fund investments in 1999 resulted in the average fund size increasing to 266 mil. Euros, up from only 40 mil. Euros the previous year. The supply side responded to demand during the following years, with the number of funds on offer more than doubling. Average returns of the funds are similar to the ASE General Index returns with the exception of 1998-1999, when small cap strategies yielded higher returns than the General Index, and of 2004, when the ASE General Index high returns were mainly due to large cap stocks.

The Greek financial system is oligopolistic and vertically integrated, dominated by the three largest banks, namely the National Bank of Greece, Alpha Bank and Eurobank. Their capitalization represents $24.44 \%$ of total ASE capitalisation as of December 2004, while they also hold a significant portion of the other listed companies, either directly or indirectly through their mutual fund companies. This means that they are key market players and are able to influence corporate decisions as shareholders. Furthermore, they play a significant role in short- and long-term corporate financing, being able to approve or reject business plans and monitor their implementation. This 
is another source of insider information about business prospects. Moreover, almost all IPOs have been underwritten by one or more of these banks. Even though the banks as underwriters cannot participate in the IPO directly, this is possible through their fund management companies. It is also important to note that these banking groups incorporate brokerage companies, which carry out transactions for them and their clients, being market makers too. Finally, these banks control the main fund management companies of the domestic industry, holding $55.93 \%$ of the total assets under management in December 2001, when their market share of domestic equity funds was as high as $49.41 \%$.

Therefore, it is clear that these banks play the multiple role of stockholder, lender, underwriter and investor in the financial system, which allows them to access valuable information for investment purposes. This access to higher quality and costless information gives the funds offered by these banking groups with a significant advantage over other mutual funds. Such a market structure makes it possible to exploit insider or private information, inconsistently with market efficiency, even in its strong form, and increases the informational asymmetry between fund shareholders and managers. Furthermore, the trading activity of these fund companies has not only a direct impact on prices, but, more importantly, an indirect one through a signalling effect to the other market participants. ${ }^{5}$ Under these circumstances, it would not be surprising if specific funds persistently outperformed their peers, making the case of Greece a particularly interesting one to analyse.

\footnotetext{
${ }^{5}$ An oligopolistic financial system may also lead to herding among mutual funds, since fund companies strongly want to avoid underperforming rivals, even over very short horizons.
} 


\section{Data and Methodology}

\subsection{Data}

All domestic equity funds with data available for two consecutive years have been included, and therefore the dataset is free of survivorship bias. It spans the period from 01/01/1998 to 31/12/2004. We use the Net Asset Value (NAV) of the domestic equity funds, the Athens Stock Exchange (ASE) returns as proxied by the General Index returns, the MSCI Government Bond Index and the risk-free rate as proxied by the 3-month Government ZeroCoupons. The source for the funds NAVs and Net Flows is the Association of the Greek Institutional Investors (AGII), while the other series were obtained from Datastream. Returns are calculated on a weekly basis. Data for the participation of foreign investors in the ASE were provided by the Central Depository of ASE, while the data for bond holdings were collected by hand from the funds' reports.

We follow Otten and Bams (2002) in constructing the strategy-mimicking portfolios. All stocks included in the ASE General Index were utilized. Ranking stocks with respect to the previous year's size, we assign the top $30 \%$ by market capitalization to the Big size portfolio and the bottom $30 \%$ to the Small size portfolio. The difference between returns to these two portfolios yields the size strategy (SMB) return. Ranking stocks according to last year's returns, the difference between the top $30 \%$ winners by market capitalization and the bottom $30 \%$ losers provides the momentum (MOM) portfolio return. Moreover, the $30 \%$ of stocks with the highest book-to-market-value ratio were assigned to the High Value portfolio, and the 30\% of stocks with the lowest ratio to the Low Value portfolio. The difference between their respective returns yields the book-to-market value (HML) strategy returns. All returns were calculated on a weekly basis and the portfolios were annually rebalanced. ${ }^{6}$

\footnotetext{
${ }^{6}$ We have also used other similar percentages as cutoff points for constructing the
} 


\subsection{Performance measures}

Raw returns of the mutual funds were calculated using the standard formula:

$$
R_{p}=\frac{N A V_{t}-N A V_{t-1}}{N A V_{t-1}}
$$

These are employed as our first performance measure. Next we use the Sharpe ratio, which measures fund excess returns adjusted for their riskiness; it is given by the ratio:

$$
S R=\frac{R_{p}-R_{f}}{\sigma_{p}}
$$

where $R_{f}$ is the risk-free rate and $\sigma_{p}$ is the standard deviation of the fund returns.

Jensen's alpha measures the ability of the mutual fund manager to add value over and above the return which would be justified by the systematic risk of his portfolio. Formally, this is given by the intercept $\alpha_{\text {Jensen }}$ of the regression of the fund excess returns on the market index excess returns:

$$
R_{p}-R_{f}=\alpha_{\text {Jensen }}+\beta_{M}\left(R_{M}-R_{f}\right)+\epsilon_{t}
$$

where $R_{m}$ is the stock market return.

The intercept of this single-factor model has also been used to infer the "stock picking" ability or "selectivity" of the manager. This model can be augmented to include returns on government bonds. It should be noted that domestic equity funds invest a portion of their assets in government bonds, in order to reduce their stock market exposure when managers have a negative view for prospective returns, and to earn a higher interest rate for their nonstock holdings. A domestic equity fund has the obligation to invest at least $65 \%$ of its total assets in ASE stocks according to the Greek mutual funds legislation. As a result, non-stock holdings can be significantly high. Since

strategies portfolios - the results were almost identical and are available from the authors upon request. 
a performance measure estimates the value a manager adds to his portfolio over and above the returns justified by known risk factors, Elton et al. (1996) and Gruber (1996) suggest that the excess bond return should be included in order to allow for fund returns from bond holdings. Hence, the augmented model is given by:

$$
R_{p}-R_{f}=\alpha_{\text {Jensen }}+\beta_{M}\left(R_{M}-R_{f}\right)+\beta_{B}\left(R_{B}-R_{f}\right)+\epsilon_{t}
$$

Moving on to multi-factor models, the three-factor model of Fama and French (1996) employed here is the following:

$$
R_{p}-R_{f}=\alpha_{F F}+\beta_{M}\left(R_{M}-R_{f}\right)+\beta_{1} S M B+\beta_{2} H M L+\epsilon_{t}
$$

The intercept of this regression is interpreted as a performance measure. Following this approach, we are able to capture excess returns generated by tactical asset allocation strategies exploiting the inconsistencies of the CAPM. More specifically, excess fund returns are decomposed into excess market returns, returns generated by buying small size stocks and selling big size stocks (Small Minus Big- SMB), and returns generated by buying stocks with high book-to-market ratios and selling stocks with low book-to-market ratios (High Minus Low- HML). The intercept of this regression represents the value the manager has added to his portfolio over and above what could be justified by market risk and generated by these known strategies.

One step further, we use the Carhart (1997) measure, which builds on the Fama and French model but also captures returns generated by the momentum effect as analyzed in Jegadeesh and Titman (1993). This strategy (MOM) implies buying and selling stocks with high and low past year's returns respectively.

The four-factor model is given by:

$$
R_{p}-R_{f}=\alpha_{\text {Carhart }}+\beta_{M}\left(R_{M}-R_{f}\right)+\beta_{1} S M B+\beta_{2} H M L+\beta_{3} M O M+\epsilon_{t}
$$


The intercept of this regression- $\alpha_{\text {Carhart }}{ }^{-}$can be used as a performance measure and it takes into account not only market risk but also excess returns generated by these well-documented strategies.

Lastly, the four-factor model is augmented to include the bond index return. We would argue that the intercept of this regression- $\alpha_{A C^{-}}$is the most appropriate performance measure to solve the ex post verification problem, since it also includes bond returns, which, as already mentioned, are used effectively by managers to reduce market risk exposure in a bear market:

$R_{p}-R_{f}=\alpha_{A C}+\beta_{M}\left(R_{M}-R_{f}\right)+\beta_{1} S M B+\beta_{2} H M L+\beta_{3} M O M+\beta_{B}\left(R_{B}-R_{f}\right)+\epsilon_{t}$

\subsection{Non-parametric tests}

In order to test the persistence hypothesis, contingency tables for each of the measures presented above are constructed and a series of non-parametric tests are carried out. These are the Z-test proposed by Malkiel (1995), the cross-product ratio test of Brown and Goetzmann (1995), and the chi-squared test of Kahn and Rudd (1995). To construct these test statistics, we classify the mutual funds as winners (W) or losers (L) depending on whether their performance measure was above or below the median value for each time period.

As we only have estimates of performance, instead of ranking funds using only the point estimates, we also take into account whether these are significantly different from zero. Therefore, we firstly rank the funds with positive and significant estimates, then those with measures not significantly different from zero, and finally those with negative and significant estimates. Clearly, ranking as a top winner (loser) a fund with a high (low), but insignificantly different than zero, point estimate of its performance measure would generate spurious results. 
The null hypothesis for these three non-parametric tests is that of no persistence. In the Malkiel (1995) test, no persistence means that a past winner will be either winner or loser next period with equal probability $p=$ 0.5 . The test statistic is calculated as follows:

$$
M=\frac{(W W-(W W+W L) * 0.5)}{\sqrt{(W W+W L) * 0.5 * 0.5}}
$$

and it follows a standard normal distribution.

In the test of Brown and Goetzmann (1995) the null hypothesis is that the number of funds changing category next period is equal to the number of funds remaining in the same category. The hypothesis is tested using the cross-product ratio (CPR):

$$
C P R=\frac{W W * L L}{W L * L W}
$$

Values of the statistic greater than unity indicate persistence, while values smaller than unity indicate reversal. For the statistical significance of the test values, the following Z-test is constructed:

$$
Z=\frac{\ln C P R}{\sigma_{\ln C P R}}
$$

where

$$
\sigma_{\ln (C P R)}=\sqrt{\frac{1}{W W}+\frac{1}{L L}+\frac{1}{W L}+\frac{1}{L W}}
$$

Finally, Kahn and Rudd (1995) use a chi-square test, which compares the observed with the expected frequency of an event. In the case of no persistence, the expected number of winners remaining winners is equal to the expected number of winners turning losers, as well as the number of losers remaining losers and the number of losers becoming winners. Cortez et al. (1999) specify this chi-square statistic as: 


$$
\chi^{2}=\frac{(W W-N / 4)^{2}}{N / 4}+\frac{(W L-N / 4)^{2}}{N / 4}+\frac{(L W-N / 4)^{2}}{N / 4}+\frac{(L L-N / 4)^{2}}{N / 4}
$$

which follows a chi-square distribution with one degree of freedom.

\section{Empirical Results}

This section presents the results of the non-parametric tests for the performance measures discussed in the previous section. The persistence hypothesis is tested on an annual basis in all cases.

\subsection{Raw returns}

The first measure used is raw returns. The classification of the funds across time and the statistics of the non-parametric tests are given in Table 3. There is significant evidence of persistence in 3 out of the 6 examined periods (199899, 2000-01, 2003-04). Throughout, past winners have significantly higher probability $(57 \%)$ to remain winners than to turn losers next period.

Such persistence could be mainly explained by the investment strategy of the funds. Since raw returns are not adjusted for risk, equity funds which invest in highly volatile stocks are more likely to be characterized as winners in periods with positive market returns and as losers in periods with negative market returns. Therefore, persistence is observed more often in years with the same sign for market returns. On the other hand, when the stock market trend is reversed, as in the period 2002-2003, past winners are more likely to become losers (only $41 \%$ of the past winners remained winners in this period). Clearly, such a performance measure is inefficient and it can lead to spurious results, since persistence is due mainly to market returns, rather than managerial ability.

$$
\text { -Table } \quad 3-
$$




\subsection{Sharpe Ratio}

By contrast, the Sharpe ratio adjusts funds returns for risk using their standard deviation, thereby taking into account the volatility of the investment strategy. Table 4 reports the results for the persistence hypothesis using this measure. Significant persistence is observed, mainly during the same three periods as in the case of raw returns. Interestingly, overall persistence is even more significant, as $59 \%$ of past winners are classified as winners in the following year too.

The persistence reported here is due to the fact that a number of funds managed to achieve high excess returns without undertaking higher volatility risk. Hence, some classes of stocks had higher returns than other classes with the same volatility. The funds which invested in these classes of stocks managed to achieve persistently higher Sharpe ratios.

$$
\text { -Table } \quad 4-
$$

\section{$5.3 \quad$ Jensen's measure}

The next measures used are Jensen's alpha (regression 3) and the intercept of the augmented market model (regression 4). Table 5 and Table 6 report the results for these measures. When using Jensen's alpha we find evidence of persistence in 2000-2001 as well as in 2003-2004, while the augmented model implies that persistence in these periods is not statistically significant. Compared to the results obtained using the Sharpe ratio, persistence is now marginally lower, reflecting the difference between systematic risk as measured in the market model and fund riskiness as captured by the Sharpe ratio.

Throughout the periods analysed, past winners (losers) are still more likely to remain winners (losers), but the augmented model reduces persistence further. As Elton et al. (1996) and Gruber (1996) have suggested, 
an appropriate performance measure should adjust for bond returns, since equity funds are allowed to invest a significant portion of their non-stock holdings in short- or long-term bonds. As Figure 3 shows, managers significantly increased their bond holdings during the bear market of 2000-2003. This strategy was reversed in 2003, when stock prices started to rise again. Hence, it can be argued that investment in assets other than equity is the outcome of a deliberate strategy and, therefore, one should account for the corresponding returns.

The superiority of the augmented model can be illustrated through an example. The stock market faced significant negative returns in the period 2000-2001. Some equity funds shifted part of their assets to bonds. The single-factor model may result in a biased fund beta and attribute bond returns to Jensen's alpha, leading to the classification of such a fund as a winner. This is the reason why we find persistence in this period (see Table 5). On the other hand, the augmented model correctly assigns these returns to the exposure to the risk associated with bond returns. As a result, no significant persistence is now observed during this period (see Table 6): as one correctly adjusts for risk, the evidence for persistence weakens. Returns, which were previously characterized as abnormal, are now explained in term of known risk factors.

$$
\begin{array}{ll}
- \text { Table } & 5- \\
- \text { Table } & 6-
\end{array}
$$

\subsection{Fama-French and Carhart measures}

Next we use the Fama-French model (see regression 5) to adjust for known sources of risk. As already explained in Section 3, this regression incorporates portfolio strategies, which exploit the size and book-to-market anomalies documented in Fama and French $(1993,1996)$. Using this regression, we adjust for returns generated by strategies which invest in small and value stocks. 
This is quite important because the ASE General Index is highly dependent on a few large capitalization stocks. Therefore, for periods during which the returns of small size stocks significantly exceed the returns of the large capitalization stocks, the single-factor model will assign these excess returns to positive performance. Hence, funds which follow small cap strategies will appear to have positive or negative performance, which persists through time, even though this is solely due to the investment strategy.

Table 7 reports the results for persistence using as a performance measure the intercept of regression (5). There is significant evidence of persistence during the period 2000-2001, and only weak evidence during 1998-1999.

$$
- \text { Table } \quad 7-
$$

We augment the Fama and French regression adding the momentum strategy returns. The intercept of regression (6) is Carhart's alpha. ASE returns exhibit significant serial correlation, especially during pronounced upward or downward movements. This is a well known characteristic, and fund managers are expected to employ tactical asset allocation schemes to capture momentum. In a small market with oligopolistic mutual fund industry, momentum strategies may be even more important, since fund managers tend to mimic each other. ${ }^{7}$ Therefore, "hot stocks" are highly attractive for managers who fear they might miss an upward trend.

Table 8 presents the results of the tests for persistence using Carhart's alpha as a performance measure. Evidence for significant persistence is found only during 2000-2001. Persistence is also detected during 1998-1999, but this is not statistically significant given the small number of funds (27) examined in this period. The estimates of persistence are marginally lower than those based on the previous measures. It is worth highlighting that, as can be seen from Table 8, persistence is found only in the first part of the sample (1998-2001), while after 2001 there is almost no evidence for it.

\footnotetext{
${ }^{7}$ See Wermers (1999) for a discussion on mutual fund herding.
} 


$$
- \text { Table } \quad 8-
$$

As previously argued, the intercept of regression 7 can be considered the most appropriate performance measure to solve the ex post verification problem. This is because it captures most of the strategies documented in the literature for tactical asset allocation as well as the exposure to bond returns risk. Therefore, it provides a measure of genuine added value, net of returns attributed to known risk factors. Table 9 reports the results.

$$
\text { -Table } \quad 9-
$$

These are quite interesting, since persistence is significantly lower. Overall persistence is statistically insignificant, while, after 2001, funds are more likely to change classification from year to year than to remain winners or losers. Weak evidence for persistence is found for 1998-1999, while significant persistence is documented in 2000-2001. However, this is weaker compared to the estimates based on the Carhart measure or the previous measures.

\subsection{Discussion}

The results presented above lead to some striking conclusions for the Greek mutual fund industry. Firstly, if known risk factors and documented portfolio strategies are taken into account, performance persistence almost disappears, even over short horizons, as the 1-year periods employed here. This suggests that evidence for performance persistence could be due to the failure to adjust for these factors. In particular, bond returns and momentum strategies seem to be two factors which, if omitted, can yield spurious persistence results.

Secondly, evidence of persistence is found only in the first half of the examined period. No persistence is documented after 2001. This is quite an interesting result considering the fact that the number of funds more than doubled over the three years from 1998 to 2001 (see Figure 1). On the one 
hand, it could be expected that old funds, which experienced the bear market, would be handicapped after 1999 relative to new ones entering the market. The reasons would be the massive outflows that past losers faced and the inability to get rid of badly performing stocks. On the other hand, old funds could be expected to perform better, exploiting the better quality of market research and the higher ability of their more experienced managers. It seems that these two effects, working in opposite directions in a rapidly changing market, resulted in no persistence.

To account for the lack of persistence after 2001, the role of foreign investors as well as the behaviour of the flows should also be considered. The Greek stock market started being classified as a mature market in 2000-2001, which coincides with the entry of the country into the EMU. Significant regulatory improvements took place during the 1998-1999 period of sharp price increases and the subsequent prolonged period of negative returns (20002002). The new environment enabled the share of foreign investors to rise significantly after 2001, "crowding out" noise traders (see Figure 2). More precisely, while foreign investors held only $21.62 \%$ of the total ASE capitalization in May 2001, this share had increased to 38.45\% by December 2004. The integration of the market in the international financial system and the more transparent regulatory framework would be inconsistent with persistently higher abnormal returns earned by domestic equity funds. It is likely that fund managers were able to add value to their portfolios, before 2001, by exploiting noise traders' inefficient investment strategies, and that the replacement of the noise traders with more sophisticated foreign investors after 2001 played a significant role in reducing domestic funds' abnormal returns and their persistence.

The behaviour of flows is another important factor when investigating performance persistence in open-end funds. Managers have to adjust investment decisions to the size and the timing of the flows in and out of funds. A simple way to examine the direction of flows is to classify funds according to 
specific performance measures at the end of each year, and to calculate the total flows to each fund during the following 6 months ${ }^{8}$. Table 10 compares the average flow to the top 5 funds with the average flow to the bottom 5 classified according to raw returns, the Sharpe Ratio, and the augmented Carhart measure respectively, from 1998 to 2003. In general, flows are towards past winners, classified as such on the basis of raw returns and the augmented Carhart measure, for most of the years, while the classification according to the Sharpe Ratio yields mixed results.

$$
\text { -Table 10- }
$$

Linking this evidence to the lack of persistence, one can argue that the direction of flows to past winners plays a partial, yet significant, role in preventing them from being top performers again. Being obliged to invest a significant amount (owing to the new flows) in a relatively short horizon, managers cannot be as successful as with their initial investment strategy. Hence, there is a "dilution" effect such that managers cannot consistently outperform others (see Greene and Hodges, 2002, and Berk and Greene, 2004, for a related discussion).

Finally, it should be noted that we do not find any asymmetry in performance persistence, which is contrary to US studies documenting that overall persistence is mainly due to negative persistence (see, e.g., Brown and Goetzmann, 1995 and Carhart, 1997). This finding essentially implies that managers with bad skills do not outnumber those with good skills.

\footnotetext{
${ }^{8}$ In addition to past ranking, flows are related to other fund characteristics, such as size and age, brand name and advertisement as well as personal attributes of the managers. Furthermore, the relationship between performance and flows is clearly non-linear. Nevertheless, this approach provides a good guide for the purposes of the present analysis.
} 


\section{Conclusions}

This study has analysed performance persistence in domestic equity funds in the Greek market, during a period characterized by different market phases, a remarkable increase in the number of mutual funds and the integration of the market in the international financial system. A series of performance measures suggested in the literature have been used, after discussing their assumptions and implications. The results show that, when adjusting for known risk factors and portfolio strategies, the evidence for persistence gradually weakens. Using an appropriate performance measure to test the persistence hypothesis (specifically, the augmented Carhart measure including bond returns) is crucial to solve the ex post verification problem. Unless risk factors are taken into account, the results might be spurious, making the problems arising from asymmetric information even more severe.

Performance persistence has been found in the first half of our sample, while there is no such evidence after 2001. The integration in the international financial system with the associated significant increase in the number of foreign institutional investors during this period, and the "dilution" effect generated by the direction of flows to past winners might account for the lack of persistence after 2001. Regulatory improvements and a more competitive fund industry also made the market more efficient. Moreover, no significant difference between positive and negative persistence has been documented. This might be due to the remarkable growth of the fund industry during the period under examination.

These findings could be relevant also for other emerging markets with oligopolistic and vertically integrated financial industries, which are in the process of becoming more integrated internationally. Increased international competition and the use of appropriate performance measures might increase market efficiency and reduce informational asymmetries, resulting in a lower degree of persistence. Regarding future research, it would be interesting to examine the persistence hypothesis for foreign funds investing in Greece, 
when appropriate data become available. This would shed further light on the equilibrating mechanism which has eliminated persistence after 2001. 


\section{References}

[1] Agudo L. F, M.V. Magallon, 2005. Empirical evidence of performance persistence in a relatively unexplored market: the case of Spanish investment funds. Applied Financial Economics Letters 1, 85-88.

[2] Barry C., E. Goldreyer, L. Lockwood, M. Rodriguez, 2002. Robustness of size and value effects in emerging equity markets, 1985-2000. Emerging Markets Review 3, 1-30.

[3] Berk J., R.C. Green, 2004. Mutual Fund Flows and Performance in Rational Markets. Journal of Political Economy 112, 1269-1295.

[4] Bilson C., A. Frino, R. Healey, 2005. Australian Retail Fund Performance Persistence. Accounting and Finance 45, 25-42.

[5] Blake D., A. Timmermann, 1998. Mutual Fund Performance: Evidence from the UK. European Finance Review 2, 57-77.

[6] Bollen N., J.A. Busse, 2005. Short term Persistence in Mutual Fund Performance. Review of Financial Studies 18, 569-597.

[7] Brown S., W.N. Goetzmann, R. Ibbotson, S. Ross, 1992. Survivorship Bias in Performance Studies. Review of Financial Studies 5, 553-580.

[8] Brown S. J., W.N. Goetzmann, 1995. Performance Persistence. Journal of Finance 50, 679-698.

[9] Campbell J., T. Vuolteenaho, 2004. Bad Beta, Good Beta. American Economic Review 94, 1249-1275.

[10] Carlson R. S., 1970. Aggregate Performance on Mutual Funds, 19481967. Journal of Financial and Quantitative Analysis 5, 1-32.

[11] Carhart M., 1997. On Persistence in Mutual Fund Performance. Journal of Finance 52, 52-82. 
[12] Casarin R., L. Pelizzon, A. Piva, 2002. Italian equity funds: Efficiency and Performance persistence, Working paper.

[13] Christensen M., 2005. Danish Mutual fund Performance, Selectivity, Market Timing and Persistence, Working paper.

[14] Cortez M., D.A. Paxson, M.J. Rocha, 1999. Persistence in Portuguese mutual fund performance. The European Journal of Finance 5, 342-365.

[15] Cuthbertson K., D. Nitzsche, N. O' Sullivan, 2005. Mutual fund performance: Skill or Luck?. Working Paper, Cass Business School.

[16] Dahlquist M., S. Engstrom, P. Soderlind, 2000. Performance and Characteristics of Swedish Mutual Funds. Journal of Financial and Quantitative Analysis 35, 409-423.

[17] Deaves R., 2004. Data conditioning biases, performance persistence and flows: The case of Canadian equity funds. Journal of Banking and Finance 28, 673-694.

[18] Droms W.G., D.A. Walker, 2001. Persistence of mutual fund operating characteristics: returns, turnover rates, and expense ratios. Applied Financial Economics 11, 457-466.

[19] Elton E. J., M. J. Gruber, C. R. Blake, 1996. The Persistence of RiskAdjusted Mutual Fund Performance. Journal of Business 69, 133-157.

[20] Fama E. F., K. R. French, 1993. Common Risk Factors in the Returns on Bonds and Stocks. Journal of Financial Economics 33, 3-53.

[21] Fama E. F., K. R. French, 1996. Multifactor Explanations of Asset Pricing Anomalies. The Journal of Finance 51, 55-84.

[22] Fletcher J., D. Forbes, 2002. An exploration of the persistence of UK unit trust performance. Journal of Empirical Finance 9, 475-493. 
[23] Goetzmann W. N., R. G. Ibbotson, 1994. Do Winners Repeat?. The Journal of Portfolio Management 20, 9-18.

[24] Greene J., C. Hodges, 2002. The dilution impact of daily fund flows on open-end mutual funds. Journal of Financial Economics 65, 131-158.

[25] Grinblatt M., S. Titman, 1992. The Persistence of Mutual Fund Performance. Journal of Finance 47, 1977-1984.

[26] Gruber M. J., 1996. Another Puzzle: The Growth in Actively Managed mutual Funds. Journal of Finance 51, 783-810.

[27] Hallahan T. A., R.W. Faff, 2001. Induced persistence or reversals in fund performance? The effect of survivorship bias. Applied Financial Economics 11, 119-126.

[28] Harrison M., D. Kreps, 1979. Martingales and Arbitrage in Multiperiod Security Markets. Journal of Economic Theory 20, 381-408.

[29] Harvey C., A. Siddique, 2000. Conditional Skewness in Asset Pricing Tests. Journal of Finance 55, 1263-1295.

[30] Hendricks D., J. Patel, Zeckhauser R., 1993. Hot Hands in Mutual Funds: Short -Run Persistence of Relative Performance, 1974-88. Journal of Finance 48, 93-130.

[31] Jegadeesh N., S. Titman, 1993. Returns to buying winners and selling losers: Implications for stock market efficiency. Journal of Finance 48, 65-91.

[32] Jensen M., 1968. The performance of Mutual Funds in the Period 194564. Journal of Finance 23, 389-416.

[33] Kahn R. N., A. Rudd, 1995. Does Historical Performance Predict Future Performance?. Financial Analysts Journal 51, 43-52. 
[34] Khorana, A., Servaes, H., Tuffano, P., 2005. Explaining the size of the mutual fund industry around the world. Journal of Financial Economics $78,145-185$.

[35] Lehmann B. N., D.M. Modest, 1987. Mutual Fund Performance Evaluation: A Comparison of Benchmarks and Benchmark Comparisons. Journal of Finance 42, 233-265.

[36] Malkiel B.G., 1995. Returns from Investing in Equity Mutual Funds 1971-91. Journal of Finance 50, 549-572.

[37] Markowitz, H. M., 1952. Portfolio selection. Journal of Finance 7, 77-91.

[38] Merton, R., 1973. An intertemporal capital asset pricing model. Econometrica 41, 867- 887.

[39] Otten R., D. Bams 2002. European Mutual Fund Performance. European Financial Management 8, 75-101.

[40] Phelps S., L. Detzel, 1997. The nonpersistence of mutual fund performance. Quarterly Journal of Business and Economics 36, 55-69.

[41] Petkova R., 2006. Do the Fama-French factors proxy for Innovations in Predictive variables?. Journal of Finance 56, 581-612.

[42] Rouwenhorst G., 1998. International momentum strategies. Journal of Finance 53, 267-284.

[43] Sharpe W. F., 1966. Mutual Fund Performance. Journal of Business 39, 119-138.

[44] Spencer P. (2000), The Structure and Regulation of Financial Markets, Oxford University Press.

[45] Tonks I., 2005. Performance persistence of Pension fund managers. Journal of Business 78, 1917-1942. 
[46] Vos E., P. Brown, S. Christie, 1995. A Test of Persistence in the Performance of New Zealand and Australian Equity Mutual Funds. Accounting Research Journal 8, 19-34.

[47] Wermers R., 1999. Mutual fund herding and the impact on stock prices. Journal of Finance 54, 581-622. 


\section{Appendix}

Table 1: Classification of the Literature

\begin{tabular}{|c|c|c|c|c|c|c|}
\hline Author & Year & Period & Funds & Market & Persistence & Comments \\
\hline Sharpe & 1966 & 1954-63 & 34 & US & Yes & $\begin{array}{l}\text { Past and future } \\
\text { rankings positively } \\
\text { correlated }\end{array}$ \\
\hline Jensen & 1968 & $1945-64$ & 115 & US & $\mathrm{No}$ & $\begin{array}{l}\text { No predictability } \\
\text { of future } \\
\text { performance }\end{array}$ \\
\hline Carlson & 1970 & $1948-67$ & 82 & $\overline{\mathrm{US}}$ & Yes & $\begin{array}{l}\text { Persistence in } \\
5 \text {-year but not } \\
\text { in } 10 \text {-year horizons }\end{array}$ \\
\hline $\begin{array}{l}\text { Lehmann } \\
\text { and Modest }\end{array}$ & 1987 & $1968-82$ & 130 & US & Yes & $\begin{array}{l}\text { Some evidence of } \\
\text { abnormal return } \\
\text { persistence }\end{array}$ \\
\hline $\begin{array}{l}\text { Grinblatt } \\
\text { and Titman }\end{array}$ & 1992 & $1974-84$ & 279 & US & Yes & $\begin{array}{l}\text { Weak evidence on } \\
5 \text {-year horizons }\end{array}$ \\
\hline $\begin{array}{l}\text { Hendricks, } \\
\text { Patel and } \\
\text { Zeckhauser }\end{array}$ & 1993 & $1974-88$ & 165 & US & Yes & $\begin{array}{l}\text { Persistence on } \\
\text { quarterly basis }\end{array}$ \\
\hline $\begin{array}{l}\text { Goetzmann } \\
\text { and Ibbotson }\end{array}$ & 1994 & $1976-88$ & 728 & US & Yes & $\begin{array}{l}\text { Persistence in } \\
\text { 3-year horizons }\end{array}$ \\
\hline $\begin{array}{l}\text { Kahn } \\
\text { and Rudd }\end{array}$ & 1994 & $1983-90$ & 300 & US & Partial & $\begin{array}{l}\text { Persistence for } \\
\text { bond funds } \\
\text { No for equity funds }\end{array}$ \\
\hline $\begin{array}{l}\text { Brown and } \\
\text { Goetzmann }\end{array}$ & 1995 & $1976-88$ & 829 & US & Yes & $\begin{array}{l}\text { Persistence in } \\
\text { 1-year horizons }\end{array}$ \\
\hline Malkiel & 1995 & 1971-90 & 724 & US & Partial & $\begin{array}{l}\text { Persistence in } 70 \mathrm{~s} \\
\text { not in } 80 \mathrm{~s}\end{array}$ \\
\hline
\end{tabular}


Table 1 (Continued)

\begin{tabular}{|c|c|c|c|c|c|c|}
\hline Author & Year & Period & Funds & Market & Persistence & Comments \\
\hline $\begin{array}{l}\text { Vos, Brown } \\
\text { and Christie }\end{array}$ & 1995 & 1988-94 & 26 & $\begin{array}{l}\text { New } \\
\text { Zealand }\end{array}$ & No & $\begin{array}{l}\text { No persistence for } \\
\text { raw and risk- } \\
\text { adjusted returns }\end{array}$ \\
\hline $\begin{array}{l}\text { Elton, Gruber } \\
\text { and Blake }\end{array}$ & 1996 & 1977-93 & 188 & US & Yes & $\begin{array}{l}\text { Persistence in } \\
\text { 1-year and } \\
\text { 3-year horizons } \\
\end{array}$ \\
\hline Gruber & 1996 & 1985-94 & 270 & US & Yes & $\begin{array}{l}\text { Four-factor alpha } \\
\text { exhibits predictive } \\
\text { ability }\end{array}$ \\
\hline Carhart & 1997 & $1962-93$ & 1892 & US & No & $\begin{array}{l}\text { Persistence } \\
\text { observed due } \\
\text { to momentum }\end{array}$ \\
\hline Sauer & 1997 & 1976-92 & $\begin{array}{l}\text { Morning- } \\
\text { star } \\
\text { funds }\end{array}$ & US & Partial & $\begin{array}{l}\text { No persistence } \\
\text { when adjusted } \\
\text { for style }\end{array}$ \\
\hline $\begin{array}{l}\text { Blake and } \\
\text { Timmermann } \\
\end{array}$ & 1998 & 1972-95 & 2300 & UK & Yes & $\begin{array}{l}\text { Short-term } \\
\text { persistence }\end{array}$ \\
\hline $\begin{array}{l}\text { Cortez } \\
\text { et al. }\end{array}$ & 1999 & 1994-98 & 12 & Portugal & Partial & $\begin{array}{l}\text { Persistence for } \\
\text { raw returns only }\end{array}$ \\
\hline $\begin{array}{l}\text { Jain } \\
\text { and } \mathrm{Wu}\end{array}$ & 2000 & 1994-96 & 294 & US & No & $\begin{array}{l}\text { No persistence } \\
\text { once the fund } \\
\text { is advertised }\end{array}$ \\
\hline $\begin{array}{l}\text { Dahlquist } \\
\text { et al. }\end{array}$ & 2000 & 1992-97 & 210 & Sweden & Partial & $\begin{array}{l}\text { Persistence for } \\
\text { money-market } \\
\text { funds only }\end{array}$ \\
\hline $\begin{array}{l}\text { Droms } \\
\text { and Walker }\end{array}$ & 2001 & 1971-90 & 151 & US & Yes & $\begin{array}{l}\text { Short-term } \\
\text { persistence }\end{array}$ \\
\hline
\end{tabular}


Table 1 (Continued)

\begin{tabular}{|c|c|c|c|c|c|c|}
\hline Author & Year & Period & Funds & Market & Persistence & Comments \\
\hline $\begin{array}{l}\text { Hallahan } \\
\text { and Faff }\end{array}$ & 2001 & 1989-95 & 294 & Australia & No & $\begin{array}{l}\text { Performance } \\
\text { reversal }\end{array}$ \\
\hline $\begin{array}{l}\text { Casarin } \\
\text { et al. }\end{array}$ & 2001 & 1992-99 & 57 & Italy & Yes & $\begin{array}{l}\text { Short-term } \\
\text { persistence }\end{array}$ \\
\hline $\begin{array}{l}\text { Otten } \\
\text { and Bams }\end{array}$ & 2002 & 1991-98 & 506 & Europe & Partial & $\begin{array}{l}\text { Persistence } \\
\text { only in UK }\end{array}$ \\
\hline $\begin{array}{l}\text { Fletcher } \\
\text { and Forbes }\end{array}$ & 2002 & $1982-96$ & 724 & UK & Partial & $\begin{array}{l}\text { Persistence only } \\
\text { due to lack of } \\
\text { risk adjustment }\end{array}$ \\
\hline Deaves & 2004 & 1988-98 & 300 & Canada & Yes & $\begin{array}{l}\text { Short-term } \\
\text { persistence }\end{array}$ \\
\hline $\begin{array}{l}\text { Agudo and } \\
\text { Magallon }\end{array}$ & 2005 & $1994-2000$ & 116 & Spain & Partial & $\begin{array}{l}\text { Weak evidence } \\
\text { of persistence }\end{array}$ \\
\hline $\begin{array}{l}\text { Bilson } \\
\text { et al. }\end{array}$ & 2005 & 1991-00 & 417 & Australia & No & $\begin{array}{l}\text { Persistence due } \\
\text { to lack of } \\
\text { risk-adjustment }\end{array}$ \\
\hline Christensen & 2005 & 1996-03 & 47 & Denmark & No & $\begin{array}{l}\text { No short- } \\
\text { or long-term } \\
\text { persistence }\end{array}$ \\
\hline $\begin{array}{l}\text { Bollen } \\
\text { and Busse }\end{array}$ & 2005 & $1985-95$ & 230 & US & Yes & $\begin{array}{l}\text { Persistence on } \\
\text { quarterly basis }\end{array}$ \\
\hline
\end{tabular}


Table 2: Domestic equity funds 1998-2004

\begin{tabular}{cccccc}
\hline \hline & No. funds & Av. Size (mil. E) & EW Return & VW Return & ASE Return \\
\hline \hline 1998 & 34 & 40.63 & $86.28 \%$ & $95.03 \%$ & $85.02 \%$ \\
\hline 1999 & 53 & 266.67 & $158.60 \%$ & $167.79 \%$ & $102.19 \%$ \\
\hline 2000 & 78 & 94.20 & $-45.66 \%$ & $-44.93 \%$ & $-41.52 \%$ \\
\hline 2001 & 76 & 66.66 & $-23.97 \%$ & $-24.68 \%$ & $-23.53 \%$ \\
\hline 2002 & 76 & 44.58 & $-27.24 \%$ & $-28.99 \%$ & $-32.53 \%$ \\
\hline 2003 & 69 & 60.65 & $23.40 \%$ & $24.77 \%$ & $29.46 \%$ \\
\hline 2004 & 68 & 63.57 & $10.23 \%$ & $14.94 \%$ & $23.09 \%$ \\
\hline \hline
\end{tabular}

Note: The EW Return is the annual arithmetic mean return of the funds, while the VW Return indicates the average return using weighted by the size of each fund. The ASE Return is the annual return of the ASE General Index. 
Table 3: Raw Returns

\begin{tabular}{cccccc|c|c|c|c|c}
\hline \hline \multicolumn{5}{c}{ Number of } & Percentage & Malkiel & & B\&G & \\
\hline \hline & Funds & W-W & W-L & L-W & L-L & Repeat W & Z-test & CPR & Z-stat & $\chi^{2}$ \\
\hline $1998-99$ & 27 & 9 & 4 & 4 & 10 & 0.69 & 1.39 & 5.63 & $2.05^{*}$ & $4.56^{*}$ \\
\hline $1999-00$ & 32 & 10 & 6 & 9 & 7 & 0.63 & 1.00 & 1.30 & 0.36 & 1.25 \\
\hline $2000-01$ & 46 & 13 & 10 & 7 & 16 & 0.57 & 0.63 & 2.97 & 1.76 & $3.91^{*}$ \\
\hline $2001-02$ & 64 & 19 & 14 & 12 & 19 & 0.58 & 0.87 & 2.15 & 1.50 & 2.38 \\
\hline $2002-03$ & 61 & 13 & 19 & 17 & 12 & 0.41 & -1.06 & 0.48 & -1.40 & 2.15 \\
\hline $2003-04$ & 60 & 20 & 11 & 10 & 19 & 0.65 & 1.62 & 3.45 & $2.29^{*}$ & $5.47^{*}$ \\
\hline TOTAL & 290 & 84 & 64 & 59 & 83 & 0.57 & 1.64 & 1.85 & $2.58^{*}$ & $6.86^{*}$ \\
\hline
\end{tabular}

$(*)$ denotes statistical significance at $5 \%$ level- $(* *)$ denotes statistical significance at $1 \%$ level

Table 4: Sharpe Ratio

\begin{tabular}{cccccc|c|c|c|c|c}
\hline \hline \multicolumn{5}{c}{ Number of } & Percentage & Malkiel & & B\&G & \\
\hline \hline Funds & W-W & W-L & L-W & L-L & Repeat W & Z-test & CPR & Z-stat & $\chi^{2}$ \\
\hline $1998-99$ & 27 & 9 & 4 & 4 & 10 & 0.69 & 1.39 & 5.63 & $2.05^{*}$ & $4.56^{*}$ \\
\hline $1999-00$ & 32 & 10 & 6 & 8 & 8 & 0.63 & 1.00 & 1.67 & 0.71 & 1.00 \\
\hline $2000-01$ & 46 & 12 & 11 & 6 & 17 & 0.52 & 0.21 & 3.09 & 1.78 & $5.30^{*}$ \\
\hline $2001-02$ & 64 & 20 & 13 & 12 & 19 & 0.61 & 1.22 & 2.44 & 1.74 & 3.13 \\
\hline $2002-03$ & 61 & 16 & 16 & 14 & 15 & 0.5 & 0.00 & 1.07 & 0.13 & 0.18 \\
\hline $2003-04$ & 60 & 21 & 10 & 9 & 20 & 0.68 & $1.98^{*}$ & 4.67 & $2.77^{* *}$ & $8.13^{* *}$ \\
\hline TOTAL & 290 & 88 & 60 & 53 & 89 & 0.59 & $2.30^{* *}$ & 2.46 & $3.74^{* *}$ & $14.47^{* *}$ \\
\hline
\end{tabular}

$\left(^{*}\right)$ denotes statistical significance at $5 \%$ level- $\left(^{* *}\right)$ denotes statistical significance at $1 \%$ level 
Table 5: Jensen alpha

\begin{tabular}{cccccc|c|c|c|c|c}
\hline \hline \multicolumn{5}{c}{ Number of } & Percentage & Malkiel & & B\&G & \\
\hline \hline & Funds & W-W & W-L & L-W & L-L & Repeat W & Z-test & CPR & Z-stat & $\chi^{2}$ \\
\hline $1998-99$ & 27 & 8 & 5 & 5 & 9 & 0.62 & 0.83 & 2.88 & 1.33 & 1.89 \\
\hline $1999-00$ & 32 & 8 & 7 & 11 & 6 & 0.53 & 0.26 & 0.62 & -0.65 & 1.75 \\
\hline $2000-01$ & 46 & 15 & 8 & 6 & 17 & 0.65 & 1.46 & 5.31 & $2.59^{* *}$ & $7.39^{* *}$ \\
\hline $2001-02$ & 64 & 18 & 15 & 13 & 18 & 0.55 & 0.52 & 1.66 & 1.01 & 1.13 \\
\hline $2002-03$ & 61 & 16 & 15 & 14 & 16 & 0.52 & 0.18 & 1.22 & 0.39 & 0.18 \\
\hline $2003-04$ & 60 & 20 & 11 & 9 & 20 & 0.65 & 1.62 & 4.04 & $2.54^{* *}$ & $6.80^{*}$ \\
\hline TOTAL & 290 & 85 & 61 & 58 & 86 & 0.58 & $1.99^{*}$ & 2.07 & $3.04^{* *}$ & $9.39^{* *}$ \\
\hline
\end{tabular}

(*) denotes statistical significance at $5 \%$ level- $(* *)$ denotes statistical significance at $1 \%$ level

Table 6: Augmented Jensen

\begin{tabular}{cccccc|c|c|c|c|c}
\hline \hline \multicolumn{5}{c}{ Number of } & Percentage & Malkiel & & B\&G & \\
\hline \hline & Funds & W-W & W-L & L-W & L-L & Repeat W & Z-test & CPR & Z-stat & $\chi^{2}$ \\
\hline $1998-99$ & 27 & 9 & 4 & 4 & 10 & 0.69 & 1.39 & 5.63 & $2.05^{*}$ & $4.56^{*}$ \\
\hline $1999-00$ & 32 & 10 & 6 & 9 & 7 & 0.63 & 1.00 & 1.30 & 0.36 & 1.25 \\
\hline $2000-01$ & 46 & 13 & 11 & 7 & 15 & 0.54 & 0.41 & 2.53 & 1.51 & 3.04 \\
\hline $2001-02$ & 64 & 17 & 17 & 15 & 15 & 0.50 & 0.00 & 1.00 & 0.00 & 0.25 \\
\hline $2002-03$ & 61 & 17 & 15 & 13 & 16 & 0.53 & 0.35 & 1.39 & 0.65 & 0.57 \\
\hline $2003-04$ & 60 & 18 & 13 & 11 & 18 & 0.58 & 0.90 & 2.27 & 1.55 & 2.53 \\
\hline TOTAL & 290 & 84 & 66 & 59 & 81 & 0.56 & 1.47 & 1.75 & $2.35^{*}$ & $5.92^{*}$ \\
\hline
\end{tabular}

$(*)$ denotes statistical significance at $5 \%$ level- $(* *)$ denotes statistical significance at $1 \%$ level 
Table 7: Three-factor Fama and French

\begin{tabular}{cccccc|c|c|c|c|c}
\hline \hline \multicolumn{5}{c}{ Number of } & Percentage & Malkiel & & B\&G & \\
\hline \hline Funds & W-W & W-L & L-W & L-L & Repeat W & Z-test & CPR & Z-stat & $\chi^{2}$ \\
\hline $1998-99$ & 27 & 9 & 4 & 5 & 9 & 0.69 & 1.39 & 4.05 & 1.71 & 3.07 \\
\hline $1999-00$ & 32 & 9 & 7 & 9 & 7 & 0.56 & 0.50 & 1.00 & 0.00 & 0.50 \\
\hline $2000-01$ & 46 & 17 & 6 & 4 & 19 & 0.74 & 2.29 & 13.46 & $3.58^{* *}$ & $15.04^{* *}$ \\
\hline $2001-02$ & 64 & 17 & 17 & 15 & 15 & 0.50 & 0.00 & 1.00 & 0.00 & 0.25 \\
\hline $2002-03$ & 61 & 16 & 16 & 14 & 15 & 0.50 & 0.00 & 1.07 & 0.13 & 0.18 \\
\hline $2003-04$ & 60 & 17 & 14 & 13 & 16 & 0.55 & 0.54 & 1.49 & 0.77 & 0.67 \\
\hline TOTAL & 290 & 85 & 64 & 60 & 81 & 0.57 & 1.72 & 1.79 & $2.46^{* *}$ & $6.30^{* *}$ \\
\hline
\end{tabular}

$\left({ }^{*}\right)$ denotes statistical significance at $5 \%$ level- $\left({ }^{* *}\right)$ denotes statistical significance at $1 \%$ level

Table 8: Carhart alpha

\begin{tabular}{cccccc|c|c|c|c|c}
\hline \hline \multicolumn{5}{c}{ Number of } & Percentage & Malkiel & & B\&G & \\
\hline \hline Funds & W-W & W-L & L-W & L-L & Repeat W & Z-test & CPR & Z-stat & $\chi^{2}$ \\
\hline $1998-99$ & 27 & 9 & 4 & 5 & 9 & 0.69 & 1.39 & 4.05 & 1.71 & 3.07 \\
\hline $1999-00$ & 32 & 9 & 7 & 10 & 6 & 0.56 & 0.50 & 0.77 & -0.36 & 1.25 \\
\hline $2000-01$ & 46 & 15 & 7 & 4 & 20 & 0.68 & 1.71 & 10.71 & $3.32^{* *}$ & $14.00^{* *}$ \\
\hline $2001-02$ & 64 & 16 & 15 & 15 & 18 & 0.52 & 0.18 & 1.28 & 0.49 & 0.38 \\
\hline $2002-03$ & 61 & 16 & 15 & 14 & 16 & 0.52 & 0.18 & 1.22 & 0.39 & 0.18 \\
\hline $2003-04$ & 60 & 16 & 15 & 14 & 15 & 0.52 & 0.18 & 1.14 & 0.26 & 0.13 \\
\hline TOTAL & 290 & 81 & 63 & 62 & 84 & 0.56 & 1.50 & 1.74 & $2.34^{* *}$ & $5.59^{*}$ \\
\hline
\end{tabular}

$(*)$ denotes statistical significance at $5 \%$ level- $(* *)$ denotes statistical significance at $1 \%$ level 
Table 9: Augmented Carhart

\begin{tabular}{cccccc|c|c|c|c|c}
\hline \hline \multicolumn{5}{c}{ Number of } & Percentage & Malkiel & & B\&G & \\
\hline \hline Funds & W-W & W-L & L-W & L-L & Repeat W & Z-test & CPR & Z-stat & $\chi^{2}$ \\
\hline $1998-99$ & 27 & 9 & 4 & 5 & 9 & 0.69 & 1.39 & 4.05 & 1.71 & 3.07 \\
\hline $1999-00$ & 32 & 9 & 7 & 8 & 8 & 0.56 & 0.50 & 1.29 & 0.35 & 0.25 \\
\hline $2000-01$ & 46 & 15 & 8 & 6 & 17 & 0.65 & 1.46 & 5.31 & $2.59^{* *}$ & $7.39^{* *}$ \\
\hline $2001-02$ & 64 & 16 & 18 & 16 & 14 & 0.47 & -0.34 & 0.78 & -0.50 & 0.50 \\
\hline $2002-03$ & 61 & 15 & 17 & 15 & 14 & 0.47 & -0.35 & 0.82 & -0.38 & 0.31 \\
\hline $2003-04$ & 60 & 15 & 16 & 14 & 15 & 0.48 & -0.18 & 1.00 & 0.01 & 0.13 \\
\hline TOTAL & 290 & 79 & 70 & 64 & 77 & 0.53 & 0.74 & 1.36 & 1.30 & 1.94 \\
\hline
\end{tabular}

$(*)$ denotes statistical significance at $5 \%$ level- $(* *)$ denotes statistical significance at $1 \%$ level 
Table 10: Direction of Flows ('000 €)

\begin{tabular}{ccccccc}
\hline \hline \multicolumn{7}{c}{ Panel A: Raw Returns } \\
\hline \hline Top 5 & 1998 & 1999 & 2000 & 2001 & 2002 & 2003 \\
\hline Bottom 5 & 34,192 & $-7,756$ & 28,724 & $-1,982$ & -233 & 2,340 \\
\hline \hline \multicolumn{7}{c}{ Panel B: Sharpe Ratio } \\
\hline \hline 1998 & -806 & $-1,143$ & -340 & $-2,135$ & -241 \\
\hline Top 5 & 92,495 & $-3,840$ & -839 & $-2,514$ & -216 & 1,037 \\
\hline Bottom 5 & 34,446 & $-2,221$ & -385 & 261 & -736 & $-3,729$ \\
\hline \hline \multicolumn{7}{c}{ Panel C: Augmented Carhart } \\
\hline \hline Top 5 & 1998 & 1999 & 2000 & 2001 & 2002 & 2003 \\
\hline Bottom 5 & 34,446 & -49 & -673 & -398 & -531 & -241 \\
\hline \hline
\end{tabular}

Note: Table 10 presents the average total flow over the next 6 months to the Top 5 and Bottom 5 funds, classified as such according to their Raw returns, Sharpe Ratio and augmented Carhart measure at the end of each year, 1998-2003. 
Figure 1: The ASE General Index and the Number of Domestic Equity funds, 1998-2004.

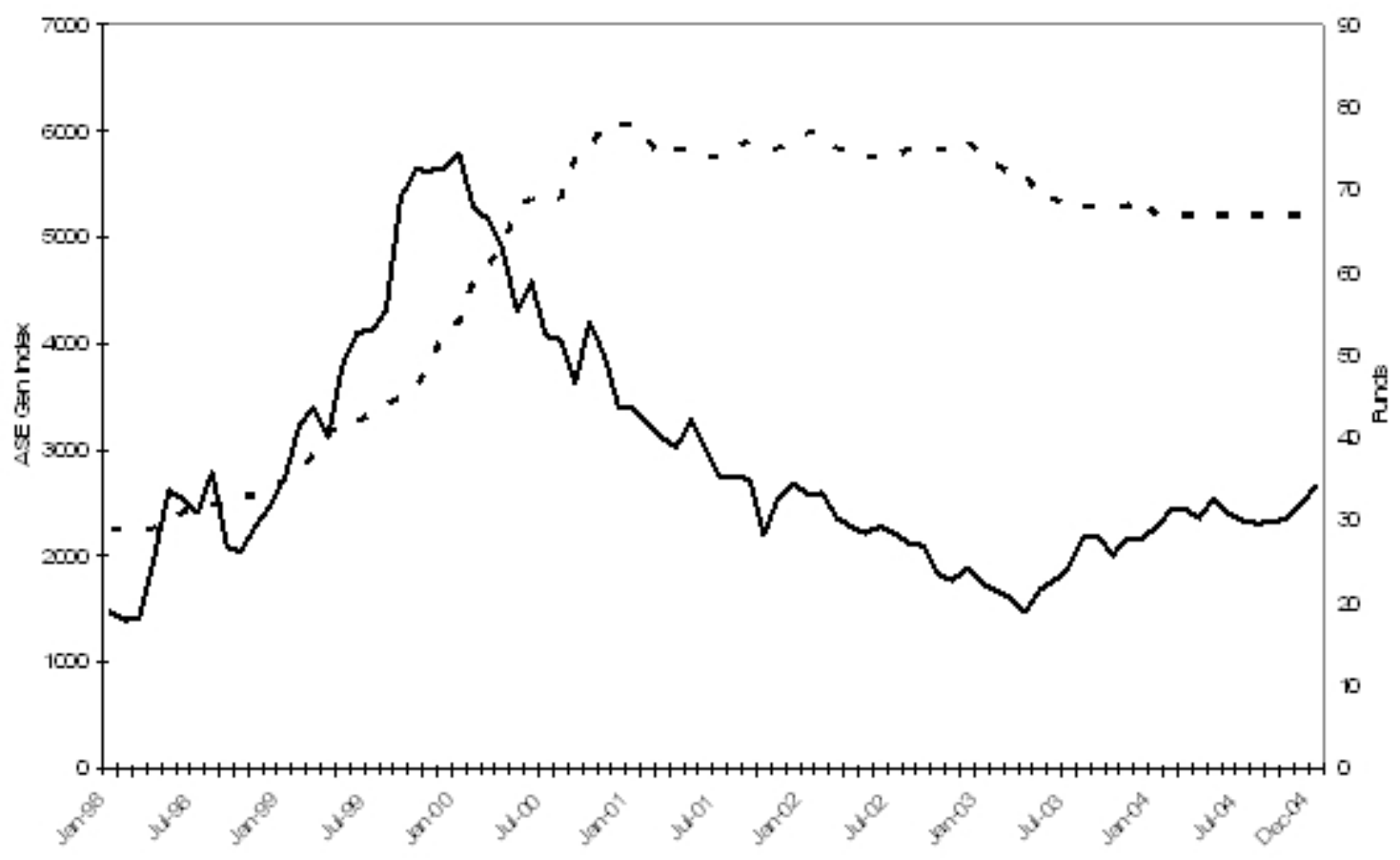

Note: The continuous line (left scale) shows the ASE General Index and the dashed line (right scale) shows the number of domestic equity funds from 1998-2004 
Figure 2: Holdings of foreign and individual domestic investors as a percentage of total ASE capitalisation, 2001-2004.

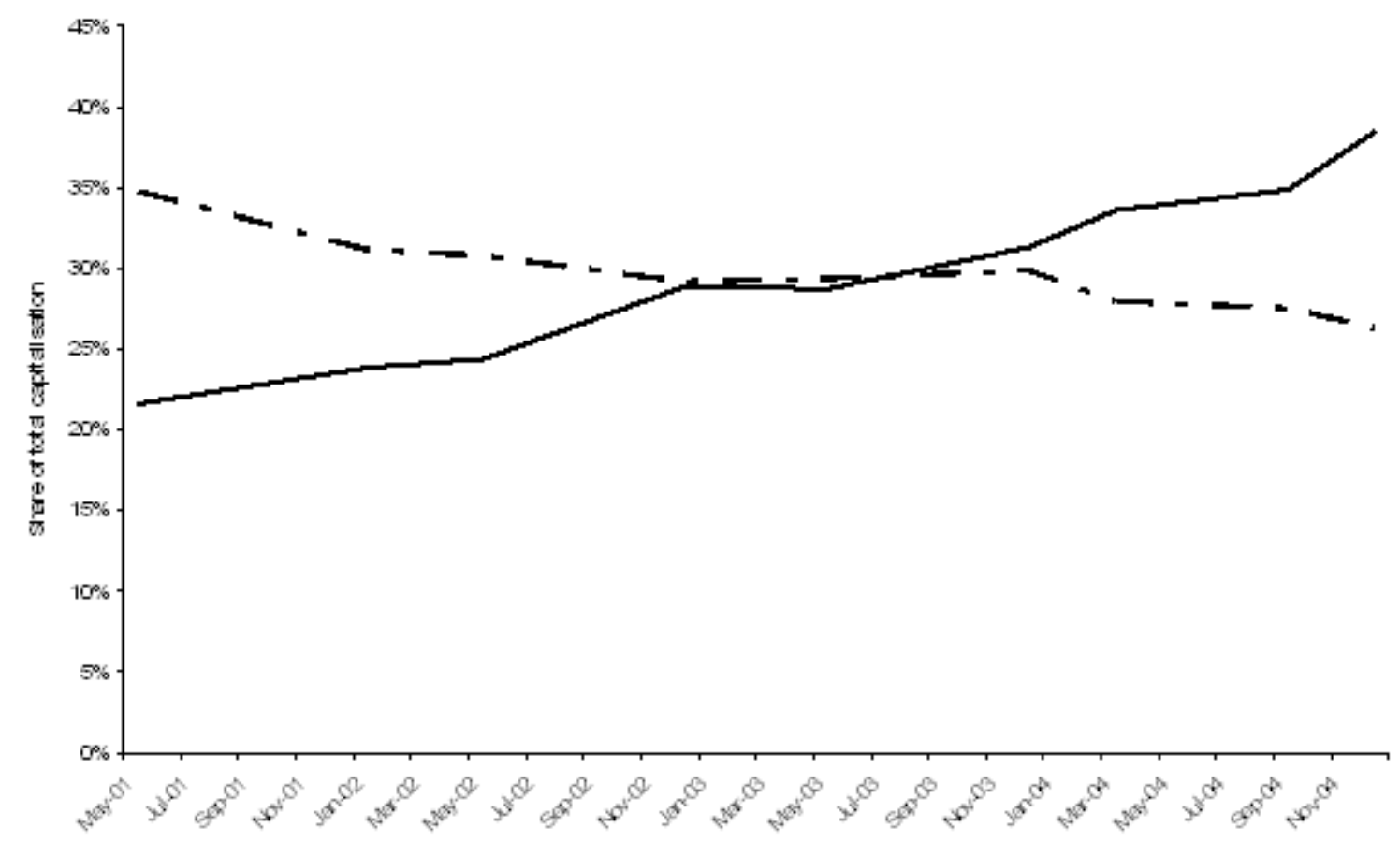

Note: The continuous line shows the share of the ASE capitalisation held by foreign investors and the dashed line shows the corresponding share by domestic individuals. 
Figure 3: Bond holdings of domestic equity funds as a percentage of their total assets under management, 2000-2004.

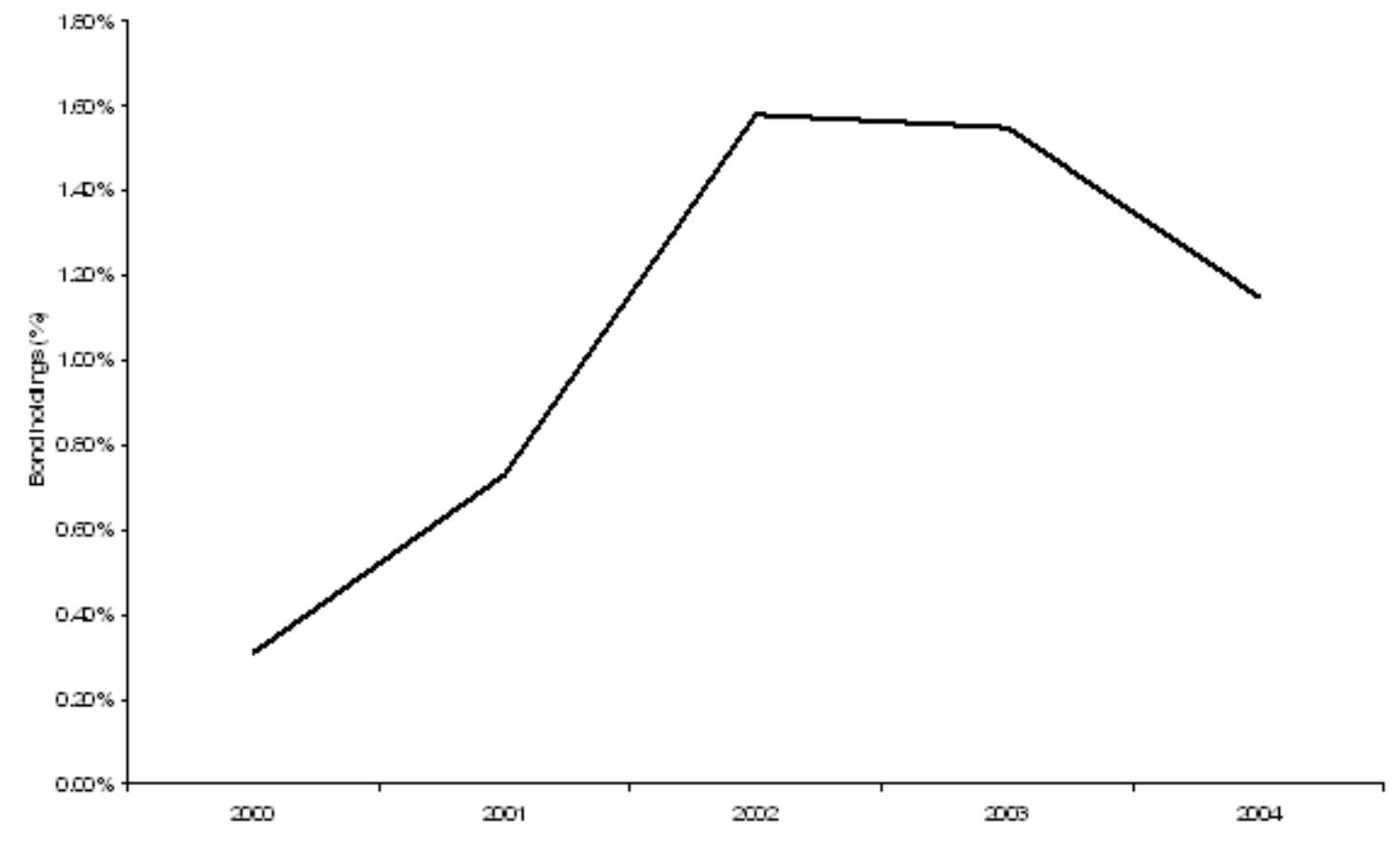

